Keenan J. Trisomy 18 and maternal serum and amniotic fluid alphafetoprotein. Prenat Diagn 1987;7:511-9.

15 Canick JA, Palomaki GE, Osthanondh R. Prenatal screening for trisomy 18 in the second trimester. Prenat Diagn 1990;10:546-8.

16 Darnule A, Schmidt D, Weyland B, Greenberg F, Rose E, Alpert E. Serum human chorionic gonadotropin, alpha fetoprotein and unconjugated estrio levels in trisomy 18 pregnancies in mid-trimester. $\mathrm{Am} f$ Hum Genet 1990;47:272a.

17 Norgaard-Pedersen B, Larsen SO, Arends J, Svenstrup B, Tabor A. Maternal serum markers in screening for Down syndrome. Clin Gener 1990;37:35-43.

18 Heyl PS, Miller W, Canick JA. Maternal serum screening for aneuploid pregnancy by alpha-fetoprotein, human chorionic gonadotropin and unconpregnancy by alpha-fetoprotein, human chorion
jugated estriol. Obstet Gynecol 1990;76:1025-31.

19 Bogart MH, Pandian MR, Jones OW. Abnormal maternal serum chorionic gonadotrophin levels in pregnancies with fetal chromosome abnormalities. Prenat Diagn 1987;7:623-30

20 Crossley JA, Aitken DA, Connor JM. Prenatal screening for chromosome abnormalities using maternal serum chorionic gonadotrophin, alphafetoprotein and age. Prenat Diagn 1991;11:83-101.

21 Greenberg F, Schmidt D, Darnule AT, Weyland BR, Rose E, Alpert E. Maternal serum alpha-fetoprotein, human chorionic gonadotropin and unconjugated estriol levels in mid-trimester trisomy 18 pregnancies. $A m$ Obstet Gynecol 1992;166:1388-92.

22 Staples AJ, Robertson EF, Ranieri E, Ryall RG, Haan EA. A maternal serum screen for trisomy 18: an extension of maternal serum screening for Down syndrome. Am 7 Hum Genet 1991;49:1025-3

23 Spencer K, Carpenter P. Screening for Down's syndrome using serum alphafetoprotein: a retrospective study indicating caution. BMF 1985;290: 1940-3.

24 Macri JN, Spencer K, Anderson RW, Cook EJ. Free beta chorionic gonadotropin: a cross-reactivity study of two immunometric assays used in prenatal maternal serum screening for Down's syndrome. Ann Clin Biochem 1993;30:94-8.

25 Reynolds TM, Penney MD. The mathematical basis of multivariate risk screening: with special reference to screening for Down's syndrome associated pregnancy Ann Clin Biochem 1990;27:452-8.

26 Cuckle HS, Wald NJ, Thompson SG. Estimating a woman's risk of having pregnancy associated with Down's syndrome using her age and serum alphafetoprotein levels. Br f Obstet Gynaecol 1987;94:387-402.

27 Wald NJ, Cuckle HS, Densem JW, Nanchahal K, Royston P, Chard T, et al. Maternal serum screening for Down's syndrome in early pregnancy. $B M \mathcal{f}$ $1988 ; 297: 883-7$

28 Palomaki GE, Knight GJ, Haddow JE, Canick JA, Saller DN, Panizza DS Prospective intervention trial of a screening protocol to identify fetal trisom 18 using maternal serum alpha-fetoprotein, unconjugated oestriol and human chorionic gonadotropin. Prenat Diagn 1992;12:925-30.

(Accepted 22 September 1993)

\title{
Deprivation, low birth weight, and children's height: a comparison between rural and urban areas
}

\author{
Richard Reading, Simon Raybould, Stephen Jarvis
}

Northumberland Health Authority Richard Reading, senior registrar in community paediatrics

\section{Centre for Urban and} Regional Development Studies, University of Newcastle upon Tyne Simon Raybould, research associate

\section{Department of Child} Health, University of Newcastle upon Tyne Stephen Jarvis, honorary lecturer in paediatric epidemiology

Correspondence to: Dr R Reading, Jenny Lind Department, Norfolk and Norwich Hospital, Norwich NR1 3SR.

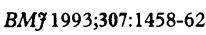

Abstract

Objective-To compare proportions of low birthweight babies and mean heights of schoolchildren between rural and urban areas at different levels of social deprivation.

Design-Cross sectional population based study classifying cases by Townsend material deprivation index of enumeration district of residence and by rural areas, small towns, and large towns.

Setting-Northumberland Health District.

Subjects-18930 singleton infants delivered alive during January 1985 to September 1990 and resident in Northumberland in October 1990; 9055 children aged 5 to $8 \frac{1}{2}$ years attending Northumberland schools in the winter of 1989-90.

Main outcome measures-Odds ratios for birth weight less than $2800 \mathrm{~g}$; difference in mean height measured by standard deviation (SD) score.

Results-Between the most deprived and most affluent $20 \%$ of enumeration districts the odds ratio for low birth weight adjusted for rural or urban setting was $1 \cdot 71(95 \%$ confidence interval 1.51 to 1.93) and the difference in mean height - $0.232 \mathrm{SD}$ score $(-0 \cdot 290$ to $-0 \cdot 174)$. Between large towns and rural areas the odds ratio for low birth weight adjusted for deprivation was $1.37(1.23$ to 1.53$)$ and the difference in mean height $-0.162 \mathrm{SD}$ score $(-0 \cdot 214$ to $-0 \cdot 110)$. Results for small towns were intermediate between large towns and rural areas.

Conclusions-Inequalities in birth weight and height exist in all rural and urban settings between deprived and affluent areas. In addition, there is substantial disadvantage to living in urban areas compared with rural areas which results from social or environmental factors unrelated to current levels of deprivation.

\section{Introduction}

Much research into social inequalities in health has concentrated on deprived urban areas and little is known about patterns of health in rural areas. ${ }^{1-3}$. Although poverty and deprivation are less visible in rural areas, there are wide variations in the social conditions in which people live. ${ }^{45}$ that are likely to be reflected in inequalities in health. There is conflicting evidence that health may be better in rural areas, ${ }^{367}$ but much of this is extrapolated from mortality data. Whether urban living itself compromises health over and above socioeconomic disadvantage or whether the poorer health in urban areas simply reflects greater deprivation is not known.

In order to move the focus of evidence away from mortality data birth weight and children's height may be used as measures of health. These vary with social circumstances $^{8-11}$ and reflect important aspects of past, present, and future health potential of children. ${ }^{810} 1213$

Studies comparing rural and urban patterns of height and birth weight while controlling for socioeconomic differences have had inconclusive results. The national study of health and growth found that children were taller in rural areas and suggested that this was due to unmeasured socioeconomic differences. ${ }^{14}$ In the north of England ${ }^{3}$ rates of low birth weight were lower in remote rural areas than in comparable urban areas, although not in rural areas which were nearer to the centres of population.

This study looks more closely into rural and urban differences in birth weight and height by using data collected for a study measuring links between child health and material deprivation in the county of Northumberland, in the north of England. There are six local authority districts within Northumberland (see fig 1). Four are predominantly rural, with low population densities, large tracts of coastal and hill country, and numerous small rural towns. The two more urban districts are in the south east of the county (Blyth Valley and Wansbeck). Wide social disparities exist in all these settings, and these have been demonstrated by using small area methods, census enumeration districts being classified by the Townsend material deprivation index. ${ }^{15}$ This enables rates of low birth weight and mean heights of primary school children to be compared between enumeration districts at equivalent levels of deprivation in different rural and urban settings.

\section{Population and methods}

Collection of the child health data has been described. ${ }^{16}$ Briefly, data on birth weight were taken from the district child health information system on a 


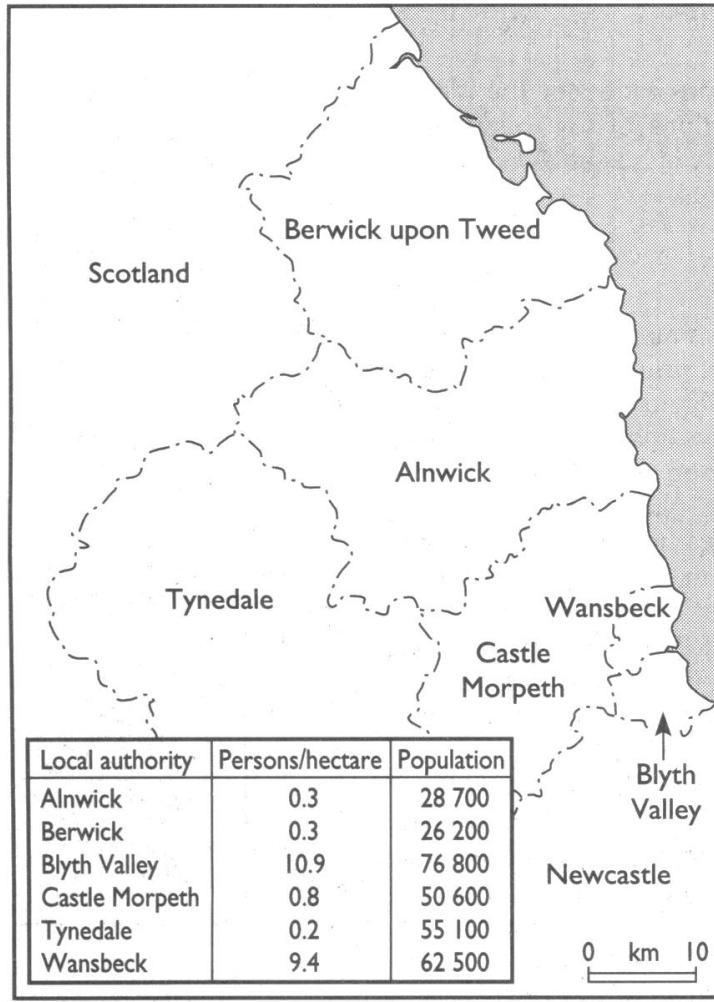

FIG 1-Map of Northumberland

cohort of all children resident in Northumberland at the time of the analysis (October 1990) and born between January 1985 and September 1990. The full cohort comprised 21702 births, though only live births of singleton infants were included in the analysis. Birth weight was available for almost all the records in the register. Low birth weight was defined as the proportion of infants delivered weighing less than $2800 \mathrm{~g}$.

Height data were collected in a survey of heights of children in three school years in all schools in Northumberland, which gave a cohort of 9930 children aged between 5.0 and 8.5 decimal years. The height of each child was measured by one of two research nurses using a Karrimeter (Raven) device, which is accurate to within $0.1 \mathrm{~cm}$. Intraobserver and interobserver reproducibility of height measurements were of the same order, with a standard deviation between measurements of $0.4 \mathrm{~cm}$ and no systematic difference in measurements between observers. By means of internal standardisation heights were converted to standard deviation (SD) scores, a 0.2 SD score being roughly equivalent to $1 \mathrm{~cm}$ around the age of 6 years. The reproducibility of the measurements and the standardisation procedure are detailed elsewhere. ${ }^{16}$

The small areas studied were census enumeration districts (the smallest areas for which census data are available), which contained an average of 150 households. Each enumeration district has a grid reference specified as the geographical centre of the population, termed the "centroid."

Each child's postcode was assigned to an enumeration district by matching to the nearest centroid by using the grid reference of both postcode and enumeration district centroids. ${ }^{17}{ }^{18}$ In about $7 \%$ of cases the system failed to match a postcode to an enumeration district, probably because of new building since the last (1981) census.

Enumeration districts were classified by the Townsend material deprivation index. ${ }^{15}$ This index is derived from four census variables: the proportion of unemployed economically active adults, the proportion of households without use of a car, the proportion of households not owner occupied, and the proportion of households with more than one person per room. The unemployment and overcrowding variables are transformed logarithmically and each variable converted to a $\mathrm{Z}$ score. The index is derived from the sum of these $Z$ scores. The scores ranged from around -8 (least deprived enumeration districts) to around 7 (most deprived enumeration districts). The enumeration districts were divided into five groups containing roughly equal proportions of the population, ranging from the most deprived $20 \%$ of enumeration districts to the least deprived $20 \%$ of enumeration districts.

An alternative method of ranking enumeration districts was according to the proportion of households that did not have use of a car. Why this is useful is presented in the results. As above, the enumeration districts were divided into groups containing roughly equal proportions of the population, from the $20 \%$ with the highest level of car non-ownership to the $20 \%$ with the lowest level of car non-ownership.

Enumeration districts were also classified by their urban or rural nature by using a modification of the method of Phillimore and Reading. ${ }^{3}$ Enumeration districts within towns of populations greater than 20000 were classed as being in large towns, those within towns of populations greater than 5000 were classed as being in small towns, and the rest were classed as rural. All the large towns lay in the two southeastern local authority districts (fig 1), the small towns were distributed across all the districts, and the rural areas were in the four rural local authority districts only.

Small area census data were extracted by using the Office of Population Censuses and Surveys SASPAC package of small area census statistics. ${ }^{19} 1981$ Census data were used, as the analyses were completed before data from 1991 became available.

\section{STATISTICS}

Statistical analysis was carried out with the SPSsx statistical package ${ }^{20}$ to produce descriptive statistics and cross tabulations, regression analyses being carried out with the GLIM package. ${ }^{21}$ Only cases with complete data were included, resulting in 18930 cases in the birthweight analyses and 9055 cases in the height analyses. There were similar proportions of cases in rural areas, small towns, and large towns. Table I shows the distribution of cases in the preschool cohort.

TABLE I-Distribution of cases from preschool cohort among Townsend deprivation score groups in different rural and urban settings. Figures are numbers of cases (\% of total cohort)

\begin{tabular}{lrrrc}
\hline $\begin{array}{l}\text { Deprivation } \\
\text { score }\end{array}$ & Rural areas & Small towns & Large towns & Total \\
\hline 1 (Deprived) & $702(3 \cdot 7)$ & $1574(8 \cdot 2)$ & $1947(10 \cdot 3)$ & $4223(22 \cdot 3)$ \\
2 & $830(4 \cdot 4)$ & $1800(9 \cdot 5)$ & $1384(7 \cdot 3)$ & $4014(21 \cdot 2)$ \\
3 & $1663(8 \cdot 8)$ & $1357(7 \cdot 2)$ & $1060(5 \cdot 6)$ & $4080(21 \cdot 6)$ \\
4 & $1709(9 \cdot 0)$ & $810(4 \cdot 3)$ & $650(3 \cdot 4)$ & $3169(16 \cdot 7)$ \\
5 (Affluent) & $583(3 \cdot 1)$ & $1327(7 \cdot 0)$ & $1534(8 \cdot 1)$ & $3444(18 \cdot 2)$ \\
\hline Total & $5487(29 \cdot 0)$ & $6868(36 \cdot 3)$ & $6575(34 \cdot 7)$ & $18930(100 \cdot 0)$
\end{tabular}

The distribution of cases in the school aged children, from which the height data were derived, was similar.

Because the data on low birth weight were proportions we used logistic regression for analysis. Data on height were analysed by using linear regression. Explanatory variables were retained in the regression models only if they reduced the deviance by a value that was significant at the $5 \%$ level. The deprivation group was entered into the model both as a linear variable and as a categoric variable. This was done to detect any non-linear effects of deprivation, but the categoric variable was removed if it did not improve the fit significantly. The rural/small town/large town variable was entered as a categoric variable. Interactions between the deprivation variables and the rural/small town/large town variable were sought 
and included in the model if they improved the fit significantly.

Results are expressed as odds ratios for the logistic regression models of proportions of low birthweight babies and as differences in mean height SD scores for the linear models of height.

\section{Results}

Figure 2 shows the proportions of low birthweight babies and the mean heights of primary school children in the three settings at different levels of material deprivation. Social inequalities may be expressed as between the most deprived group and the most affluent group while adjusting for the type of rural or urban setting. For low birth weight the odds ratio for the proportion of births less than $2800 \mathrm{~g}$ in the most deprived group in relation to the proportion in the most affluent group was 1.71 (95\% confidence interval 1.51 to 1.93$)$. The difference in mean height between the most deprived and most affluent groups was $-0 \cdot 232$ SD score $(-0 \cdot 290$ to $-0 \cdot 174)$.

There were also differences between rural areas, small towns, and large towns. Table II shows the differences when the Townsend deprivation score was adjusted for. There was an odds ratio of 1.37 for proportions of low birthweight babies in large towns in relation to rural areas and a difference in mean height of $0.162 \mathrm{SD}$ score. The measures of low birth weight and height in small towns were intermediate between large towns and rural areas. This relation between increasing urbanisation and poorer measures of height and birth weight was consistent throughout the range of deprivation.

Adding the deprivation group as a categoric variable into the regression models did not improve the fit and there were no significant interactions. We also tried including the actual deprivation score in a linear model but this gave almost exactly the same results as using the deprivation group.

The Townsend index may measure deprivation differently in rural and urban areas. If it overestimated

TABLE II-Regression modelling of rural and urban variations in low birth weight and height

\begin{tabular}{lcc}
\hline & $\begin{array}{c}\text { Odds ratio for low birth weight } \\
\text { in relation to rural areas } \\
(95 \% \text { confidence interval })\end{array}$ & $\begin{array}{c}\text { SD scores for } \\
\text { difference in mean height } \\
(95 \% \text { confidence interval })\end{array}$ \\
\hline Small towns & $\begin{array}{c}\text { Adjusted for deprivation score } \\
1.20(1.07 \text { to } 1.34)\end{array}$ & \\
Large towns & $1.37(1.23$ to 1.53$)$ & $-0.062(-0.011$ to -0.112$)$ \\
Small towns-rural areas & Adjusted for car non-ownership score & $-0.162(-0.110$ to -0.214$)$ \\
Large towns-rural areas & $1.12(1.07$ to 1.26$)$ & \\
Small towns & $1.31(1.17$ to 1.47$)$ & $-0.033(0.019$ to -0.085$)$ \\
Large towns & & $-0.144(-0.091$ to -0.197$)$ \\
Small towns-rural areas & &
\end{tabular}

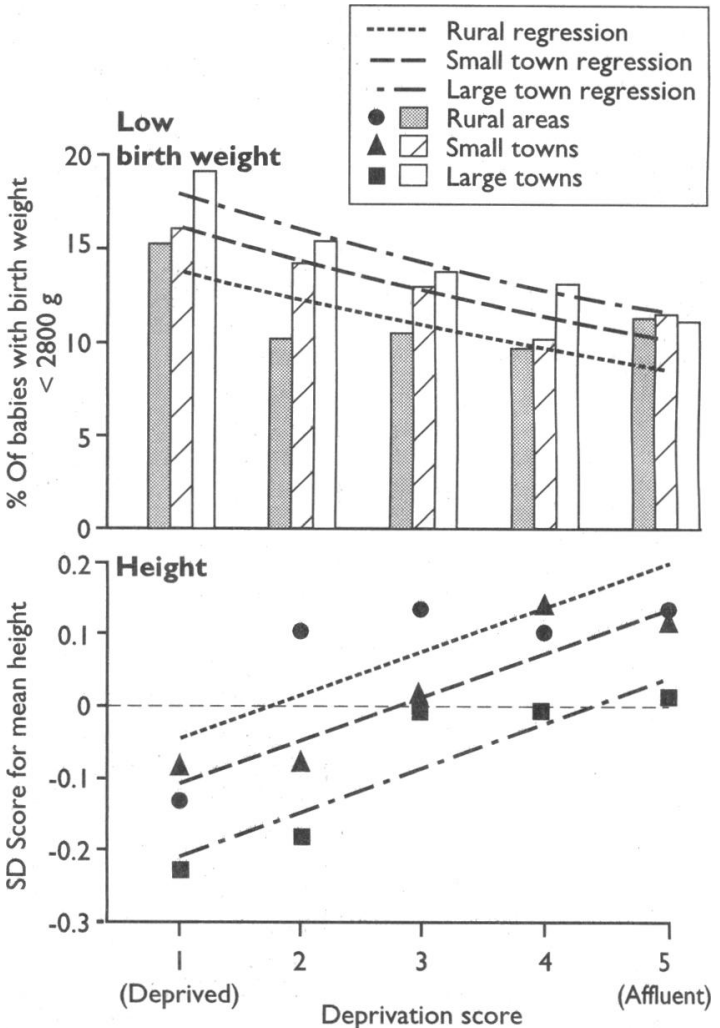

FIG 2-Proportion of low birthweight babies according to Townsend deprivation score, and mean height in each deprivation group. (Logistic regression lines shown for birth weight; linear regression lines shown for height)

deprivation in rural dwellers, then the above results might be found simply because rural dwellers at equivalent Townsend scores had better health as a result of less actual material deprivation. Evidence that this may be occurring is given in table III, which shows selected census variables in the five deprivation groups, comparing rural and urban areas. At equivalent levels of deprivation some indicators were consistently poorer in urban areas-for example, car ownership, unemployment, proportion of household heads in class I or II-whereas other indicators were poorer in rural areas-for example, overcrowding.

However, this does not necessarily imply that deprivation was overestimated in rural areas. Car ownership may be a greater priority in rural areas than urban areas, and hence at similar levels of poverty more rural dwellers may retain the use of a car. ${ }^{22}$ Moreover, low paid jobs contribute more to poverty in rural areas than in urban areas, where the main cause of low income is unemployment. ${ }^{23} \mathrm{We}$ therefore repeated the

TABLE III-Selected census statistics for rural and urban enumeration districts at different Townsend deprivation scores

\begin{tabular}{|c|c|c|c|c|c|c|c|c|c|}
\hline $\begin{array}{l}\text { Deprivation } \\
\text { score }\end{array}$ & $\begin{array}{c}\text { Enumeration } \\
\text { district }^{\star}\end{array}$ & $\begin{array}{c}\% \text { Of } \\
\text { households } \\
\text { without use of } \\
\text { cart }\end{array}$ & $\begin{array}{c}\% \text { Of } \\
\text { households } \\
\text { with use of } \\
\text { two or more } \\
\text { cars } t\end{array}$ & $\begin{array}{c}\% \text { Of } \\
\text { men aged } \\
16-64 \text { who } \\
\text { were } \\
\text { unemployed } \dagger\end{array}$ & $\begin{array}{c}\% \text { Of } \\
\text { population } \\
\text { in households } \\
\text { with } \\
\text { economically } \\
\text { active head in } \\
\text { class IV or V }\end{array}$ & $\begin{array}{c}\% \text { Of } \\
\text { population in } \\
\text { households } \\
\text { with } \\
\text { economically } \\
\text { active head in } \\
\text { class I or II } \dagger\end{array}$ & $\begin{array}{c}\% \text { Of } \\
\text { households } \\
\text { not } \\
\text { owner } \\
\text { occupied }\end{array}$ & $\begin{array}{c}\% \text { Of } \\
\text { households } \\
\text { with more } \\
\text { than one } \\
\text { person per } \\
\text { room } \neq\end{array}$ & $\begin{array}{c}\% \text { Of } \\
\text { households } \\
\text { without } \\
\text { exclusive use } \\
\text { of bath or } \\
\text { shower }\end{array}$ \\
\hline 1 (Deprived) & $\begin{array}{l}\text { Rural } \\
\text { Urban }\end{array}$ & $\begin{array}{l}62 \cdot 0 \\
64 \cdot 0\end{array}$ & $\begin{array}{l}4 \cdot 7 \\
3 \cdot 5\end{array}$ & $\begin{array}{l}15 \cdot 9 \\
21 \cdot 0\end{array}$ & $\begin{array}{l}35 \cdot 6 \\
35 \cdot 3\end{array}$ & $\begin{array}{r}10 \cdot 4 \\
6 \cdot 2\end{array}$ & $\begin{array}{l}90 \cdot 4 \\
94 \cdot 1\end{array}$ & $\begin{array}{l}6 \cdot 5 \\
5 \cdot 2\end{array}$ & $\begin{array}{l}0.5 \\
0.5\end{array}$ \\
\hline 2 & $\begin{array}{l}\text { Rural } \\
\text { Urban }\end{array}$ & $\begin{array}{l}49 \cdot 4 \\
56 \cdot 2\end{array}$ & $\begin{array}{l}8 \cdot 7 \\
5 \cdot 4\end{array}$ & $\begin{array}{l}10 \cdot 7 \\
12 \cdot 8\end{array}$ & $\begin{array}{l}24 \cdot 2 \\
29 \cdot 7\end{array}$ & $\begin{array}{l}21 \cdot 7 \\
11 \cdot 3\end{array}$ & $\begin{array}{l}78 \cdot 5 \\
75 \cdot 3\end{array}$ & $\begin{array}{l}4 \cdot 0 \\
2 \cdot 9\end{array}$ & $\begin{array}{l}0.6 \\
1.9\end{array}$ \\
\hline 3 & $\begin{array}{l}\text { Rural } \\
\text { Urban }\end{array}$ & $\begin{array}{l}33 \cdot 7 \\
50 \cdot 0\end{array}$ & $\begin{array}{r}17 \cdot 1 \\
6 \cdot 7\end{array}$ & $\begin{array}{r}6 \cdot 8 \\
10 \cdot 1\end{array}$ & $\begin{array}{l}22 \cdot 3 \\
23 \cdot 6\end{array}$ & $\begin{array}{l}37 \cdot 8 \\
15 \cdot 5\end{array}$ & $\begin{array}{l}53 \cdot 8 \\
51 \cdot 1\end{array}$ & $\begin{array}{l}2 \cdot 8 \\
2 \cdot 1\end{array}$ & $\begin{array}{l}1.5 \\
1.8\end{array}$ \\
\hline 4 & $\begin{array}{l}\text { Rural } \\
\text { Urban }\end{array}$ & $\begin{array}{l}24 \cdot 5 \\
40 \cdot 4\end{array}$ & $\begin{array}{r}23 \cdot 4 \\
8.8\end{array}$ & $\begin{array}{l}5 \cdot 2 \\
8 \cdot 4\end{array}$ & $\begin{array}{l}19 \cdot 4 \\
18 \cdot 0\end{array}$ & $\begin{array}{l}47 \cdot 3 \\
23 \cdot 3\end{array}$ & $\begin{array}{l}36 \cdot 1 \\
37 \cdot 7\end{array}$ & $\begin{array}{l}1 \cdot 7 \\
2 \cdot 1\end{array}$ & $\begin{array}{l}1.5 \\
0.8\end{array}$ \\
\hline 5 (Affluent) & $\begin{array}{l}\text { Rural } \\
\text { Urban }\end{array}$ & $\begin{array}{l}17 \cdot 9 \\
30 \cdot 9\end{array}$ & $\begin{array}{l}28 \cdot 9 \\
11.5\end{array}$ & $\begin{array}{l}3 \cdot 6 \\
6 \cdot 7\end{array}$ & $\begin{array}{l}11 \cdot 8 \\
15 \cdot 3\end{array}$ & $\begin{array}{l}61 \cdot 1 \\
30 \cdot 0\end{array}$ & $\begin{array}{l}21 \cdot 0 \\
29 \cdot 7\end{array}$ & $\begin{array}{l}1 \cdot 0 \\
1 \cdot 6\end{array}$ & $\begin{array}{l}1.3 \\
0.7\end{array}$ \\
\hline
\end{tabular}

ॠUrban enumeration districts located in Wansbeck and Blyth Valley local authority districts; rural enumeration districts located in Alnwick, Berwick, Castle Morpeth, and Tynedale districts.

tCensus measures worse in urban enumeration districts than in comparable rural enumeration districts.

$\ddagger$ Census measures worse in rural enumeration districts than in comparable urban enumeration districts. 
analysis using the proportion of households without the use of a car as the measure of deprivation between enumeration districts. At equivalent levels of car ownership measures of height and low birth weight should have been poorer in rural areas than urban areas if the previous results were due to an artefact of the measurement of material circumstances.

Figure 3 gives the results. The patterns were very similar to those in figure 2 . The odds ratio for low birth weight in areas of low car ownership in relation to areas of high car ownership was almost identical with that for deprivation score $(1.66 ; 95 \%$ confidence interval 1.46 to 1.88 ), as was the SD score for difference in mean height between areas of high and low car ownership $(-0.222 ;-0.282$ to $-0 \cdot 162)$. More important were the differences between rural areas, small towns, and large towns (table II). Odds ratios and differences in height were slightly reduced but the overall pattern was the same as when socioeconomic differences were adjusted for by deprivation score. There was no evidence of a reversal of the differences between rural areas and more urban areas.

\section{Discussion}

This study confirms that in increasingly urban settings rates of low birth weight become greater and the mean height of children becomes less. This relation is independent of levels of material deprivation, and the magnitude of the effect of urban living is quantitatively the same at all levels of deprivation. The effects of increasingly urban environments therefore represent an additional source of inequality over and above that of material circumstances. Had we included data from conurbations or large industrial centres the ruralurban differences might have been more pronounced. That we did not makes our findings all the more noteworthy.

Our measures of health were the height and birthweight distributions. Height is a reliable index of

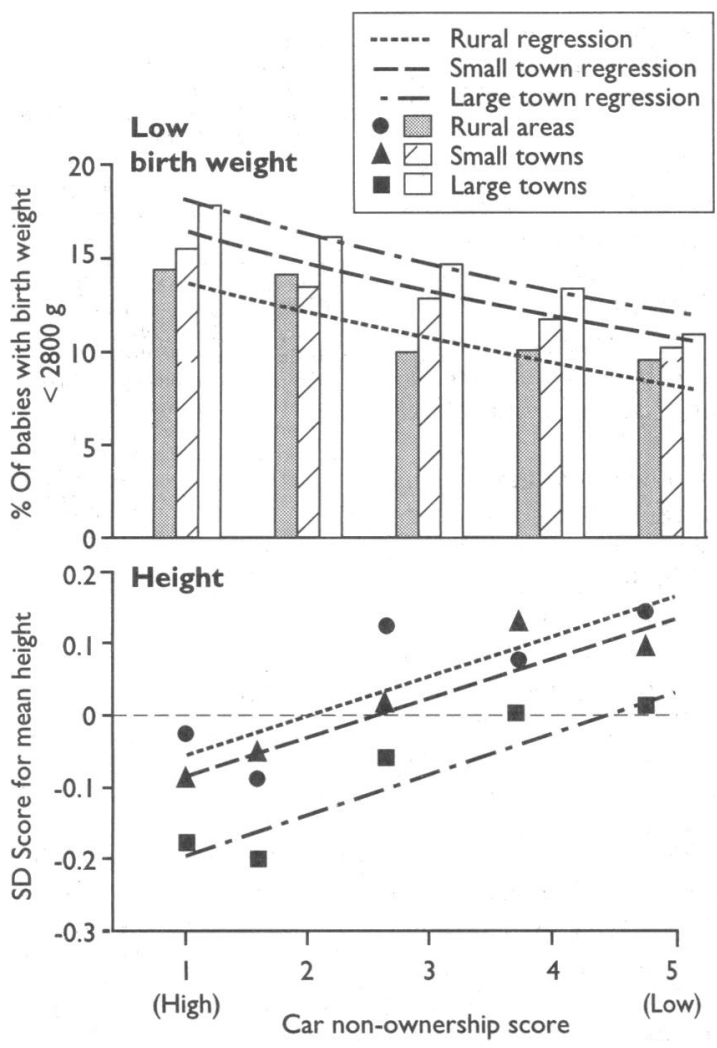

FIG 3-Proportion of low birthweight babies according to car nonownership score, and mean height in each car non-ownership group. (Logistic regression lines shown for low birth weight; linear regression lines shown for height) children's health ${ }^{13}$ but there is less agreement about birth weight less than $2800 \mathrm{~g}$. We chose this weight as a cut off rather than the more conventional $2500 \mathrm{~g}$ because the greater numbers selected would enable rates to be measured more robustly; because arguably babies of up to $3000 \mathrm{~g}$ should be categorised as of suboptimal birth weight ${ }^{24}$; and because results could be compared with other studies from the north of England. ${ }^{315}$ We could not adjust for gestation or ethnic origin because this information was not available. We accept that the index is crude but it is robust and ascertainment is reliable.

The health differences between rural and urban areas could have arisen if the Townsend score overestimated deprivation in rural areas. Arguably most conventional census based indicators tend rather to underestimate deprivation in rural areas. ${ }^{22} \mathrm{Car}$ ownership alone certainly does. Thus the validity of the observation that the urban "disadvantage" for birth weight and height remained the same was strengthened.

We could have included a large number of census variables in a regression analysis to test whether the rural-urban difference remained. We did not, however, because the choice of variables is extensive and many are correlated closely with each other. Even if a combination of variables had explained the rural-urban difference this might have been the result of chance and confounding. We therefore restricted our explanatory variables to those which specifically addressed our hypothesis. We, however, included a further social indicator which was not derived from the census in our regression analyses of height-namely, free school meal uptake by school. This indicates the uptake of means tested social security benefits. It contributed significantly to the model, though the difference between rural and urban areas was diminished only slightly and it remained highly significant (SD score for difference in mean height between large towns and rural areas $-0 \cdot 103(95 \%$ confidence interval $-0 \cdot 160$ to $-0 \cdot 046)$ ).

\section{COMPARISON WITH OTHER STUDIES}

Our findings help explain some of the inconsistencies in other studies. In a study from Scotland rates of low birth weight were compared between health boards in remote rural areas and health boards which contained major towns and cities. ${ }^{25}$ In the rural health board areas rates of low birth weight were generally lower at equivalent levels of deprivation than in the health boards containing the urban centres.

Analysis of rates of low birth weight in northern England showed the same urban disadvantage that we found when remote rural upland areas were compared with areas in conurbations. ${ }^{3}$ However, there were no differences between less remote rural areas and comparable urban areas. A possible explanation was that the less remote rural areas such as industrial, mining, and commuter villages had many "urban" characteristics. Possibly the full extent of the rural-urban differences in low birth weight was defined only in the comparison between remote rural wards and urban wards.

The most relevant comparable study of rural-urban differences in children's height was the national study of health and growth. ${ }^{14}$ That study related height to population density and found a similar difference of around $0 \cdot 1 \mathrm{SD}$ score in favour of rural children after adjustment for all measured social and biological factors. Curiously, however, latitude accounted for much of the difference, though there is no known reason why children should be smaller the further north they live. That study was complicated by biased selection, more rural areas having been sampled in the south and more urban areas in the north. The authors 


\section{Clinical implications}

- Children's health as measured by height and birth weight is better in rural areas than in urban areas

- Children's height and birth weight are poorer in deprived areas in all rural and urban settings

- Despite this the difference between rural and urban areas in height and birth weight remains after differences in deprivation have been accounted for

- The reasons for the rural health advantage are not clear but they are not an artefact

- The results support claims that children in urban areas have greater health needs than those in rural areas

suggested that latitude acted as a proxy measure of social factors which varied in a north-south gradient and were not otherwise measured. We doubt this and suggest that the rural-urban difference was genuine.

\section{CAUSES OF RURAL-URBAN DIFFERENCES}

Because of the design of our study we cannot infer the causes of the poorer measures of low birth weight and height in more urban areas. There are four general classes of explanation: that the differences were the result of external environmental factors; that they related to differences in lifestyle, culture, or social networks; that they resulted from differences in maternal health and wellbeing cumulated over past generations and transmitted to the offspring; or that they were the result of selective migration of healthy families from towns to the country.

The consistency of the difference across all levels of deprivation is evidence that the effect was related somehow to residence in a rural setting. The magnitude of the rural-urban difference argues against an environmental cause, as we can think of no environmental agent which might reasonably explain the differences. We emphasise that we were comparing rural areas with towns that were geographically adjacent.

Explanations relating to lifestyle and social networks are more plausible. There is debate about whether the greater social heterogeneity in rural areas results in alienation and a sense of isolation for poor people or facilitates a cohesive sense of community identity. ${ }^{4226}$ If social networks and support are stronger in rural areas, then this may be an explanation. There is some evidence that social support can influence birth weight. ${ }^{27}$

Studies from Aberdeen have shown how the health and viability of infants are related to the health and growth of mothers in their infancy and childhood..$^{28}$ Hart also has argued that the inherent vitality of mothers protected the pregnancies of Dutch infants conceived and borne through the hunger winter of $1945 . .^{30}$ One way in which a legacy of improved health in rural areas may have arisen is by selective migration to rural areas of healthier families. The greater proportions of families from occupational classes I and II in the rural areas at all levels of deprivation (table III) support this.

Whatever the explanations, we have shown that there is a consistent association between increasingly urban environments and poorer measures of birth weight and growth in children. These reflect similar patterns in other measures of child and adult health.
Bradley commented that it is not appropriate to say whether it is better to be poor in a rural environment than in an urban one, ${ }^{4}$ but it does seem to be healthier.

We thank Mrs Pat Waugh and Miss Gwen Charlton for collecting the height data; Northumberland Health Authority for financial support; Professor Stan Openshaw, of the School of Geography, University of Leeds, for help with geographical matching of addresses; Dr John Matthews, of the department of medical statistics, University of Newcastle upon Tyne, for advice on statistical methods; Dr Peter Phillimore for comments on the manuscript; and Miss Sarah Belding for typing.

1 Fearn R. Rural health care: a British success or a tale of unmet need? Soc Sci Med 1987;24:263-74.

2 Watt IS, Franks AJ, Sheldon TA. Rural health and health care. BMF 1993;306:1358-9.

3 Phillimore P, Reading R. A rural advantage: urban-rural health differences in northern England. I Public Health Med 1992;14:290-9.

4 Bradley T. Poverty and dependency in village England. In: Bradley T, Lowe $\mathrm{P}$, Wright $\mathrm{S}$, eds. Deprivation and welfare in rural areas. Norwich: Geo Books, 1986:151-74.

5 Walford N. Indicators of inequality as pointers to policy. In: Bradley T, Lowe , Wright $\mathrm{S}$, eds. Deprivation and welfare in nural areas. Norwich: Geo Books, 1986:109-20.

6 Chilvers C. Regional mortality 1969-73. Population Trends 1978;11:16-20

7 Bentham CG. Mortality rates in the more rural areas of England and Wales. Area 1984;16:219-26.

8 Macfarlane A, Mugford M. Birth counts: statistics of pregnancy and childbirth. London: HMSO, 1984

9 Cole T], Donnet ML, Stanfield JP. Unemployment, birthweight and growth in the first year. Arch Dis Child 1983;58:717-21.

10 MacIntyre S. A review of the social patterning and significance of measures of height, weight, blood pressure and respiratory function. Soc Sci Med 1988;27:327-37.

11 Guildford MC, Chinn S, Rona RJ. Social environment and height: England and Scotland, 1987 and 1988. Arch Dis Child 1991;66:235-40.

$12 \mathrm{McC}$ ormick MC. The contribution of low birthweight to infant mortality and childhood morbidity. N Engl F Med 1985;312:82-90.

13 Tanner JM. Physical development. BrMed Bull 1986;42:131-8.

14 Foster JM, Chinn S, Rona RJ. The relation of height of primary schoo children to population density. Int $\mathcal{f}$ Epidemiol 1983;12:199-204.

15 Townsend P, Phillimore $\mathrm{P}$, Beattie $\mathrm{A}$. Health and deprivation: inequality and the north. London: Croom Helm, 1988.

16 Reading R, Jarvis S, Openshaw S. Measurement of social inequalities in health and use of health services among children in Northumberland Arch Dis Child 1993;68:626-31.

17 Gatrell A, Dunn C, Boyle P. The relative utility of the central postcode directory and pinpoint address code in applications of geographical information systems. Environment and Planning $(A)$ 1991;23:1447-58.

18 Reading $P$, Openshaw $S$. Do inaccuracies in small area deprivation analyses matter? $\mathcal{F}$ Epidemiol Community Health 1993;47:238-41.

19 Local Authorities Management Services and Computer Committee. SASPAC user's manual (release 3.0). London: LAMSCC, 1983.

20 SPSS Inc. SPSSX user's guide. 3rd edn. Chicago: SPSS Inc, 1988

21 Numerical Algorithms Group. GLIM. Release 3.77. London: Royal Statistica Society, 1985

22 Knox $\mathrm{P}$. Methodologies and the poverty of theory. In: Bradley $T$, Lowe $\mathrm{P}$, Wright S, eds. Deprivation and welfare in rural areas. Norwich: Geo Books, 1986:99-108.

23 Walker A. Introduction and background. In: Walker A, ed. Rural poverty. London: Child Poverty Action Group, 1978: 1-14. (Poverty pamphlet No 37.)

24 Wynn M, Wynn A. Prevention of handicap and the health.of women. London: Routledge and Kegan Paul, 1979.

25 Carstairs V, Morris R. Deprivation and health in Scotland. Aberdeen: Aberdeen University Press, 1991.

26 Bradley $T$, Lowe $P$, Wright $S$. Introduction: rural deprivation and the welfare transition. In: Bradley T, Lowe $\mathrm{P}, \mathrm{W}$ right $\mathrm{S}$, eds. Deprivation and welfare in rural areas. Norwich: Geo Books, 1986: 1-42.

27 Oakley A. Social support in pregnancy: the soft way to increase birthweight. Soc Sci Med 1985;21:1259-68.

28 Illsley R. Social class selection and class differences in relation to stillbirths and infant deaths. BMf 1955;ii:1520-4.

29 Baird D. The epidemiology of low birthweight: changes in incidence in Aberdeen, 1948-72. ₹ Biosoc Sci 1974;6:323-41.

30 Hart N. Famine, maternal nutrition and infant mortality: a re-examination of the Dutch hunger winter. Population Studies 1993;47:27-46.

(Accepted 29 September 1993)

\section{Correction}

Paternal radiation exposure and leukaemia in offspring: the Ontario case-control study

An authors' error occurred in this paper by McLaughlin et al (16 October, pp 959-66). The acknowledgment should have included the following sentence: Financial support for this research was provided by the Atomic Energy Control Board of Canada. 